\title{
THE SUSTAINABLE MANAGEMENT OF TOURISM AS PART OF THE INNOVATIVE REGION MANAGEMENT BASED ON THE EUROPAN TOURISM INDICATORS SYSTEM FOR SUSTAINABLE DESTINATIONS
}

\author{
ANNA KRÓLIKOWSKA-TOMCZAK \\ State Higher Vocational School in Leszno, POLAND \\ Poznań University of Technology, POLAND \\ e-mail: krolikowska.anna@gmail.com
}

\begin{abstract}
KEYWORDS | sustainable tourism development, innovation in tourism management
ABSTRACT The article presents the concept of multifaceted management of tourism in a region by implementing the European Tourism Indicator System for Sustainable Destination developed by the European Commission. This comprehensive approach seems to be an innovative solution to the question of management of tourism which is a priority sector for the regional development, in the strict meaning of the word, for many regions of Europe. The article presents the structure of ETIS and the idea of its implementation - understood as a process - along with the notes from the regions which participated in the pilot phase of the project. The parallel assumption of the article is to disseminate the idea of sustainable tourism management in a region via the implementation of ETIS, which uses an interdisciplinary approach, thus enabling the competitiveness of the region to increase on the present-day, highly saturated, global tourism market.
\end{abstract}

Putting tourism on a sustainable path is a major challenge, but one that also presents a significant opportunity

Klaus Topfer, UNEP Executive Director

\section{Introduction}

Modern tourism is an interdisciplinary phenomenon, which means it integrates many disciplines of economy, as well as of social sciences, environment, and - taken individually - even psychology. Since the 1950s, there has been a continuous quantitative and qualitative development of the phenomenon of tourism. There is also a parallel phenomenon of the globalization of tourism: the emergence of new tourist destinations and tourist emitting regions. The widespread availability 
of tourism is a definite advantage of its development, providing self-realization, education, and regeneration of psycho-physical strength to more than a billion tourists worldwide. Still, with this scale of tourism, the scope of its effects exceeds the category of advantages and positives, presenting a significant risk, especially in the case of non-sustainable management. While the global and regional development of tourism cannot be stopped, it should be monitored. Measuring the effect of tourism on a given area makes it possible to attempt to eliminate the risks while increasing the positive aspects of the development of tourism in a region. These goals can be furthered by implementing the tool suggested by the European Committee: the European Tourism Indicators System.

The aim of the article is to present the structure and implementation process of ETIS as an innovative model for managing tourism in a region. A concurrent intention of the article is to promote the concept of sustainable tourism management in a region.

\section{Need for sustainable managagment in tourism}

\section{Tourism in the 21st century - opportunity or threat?}

The contemporary tourism is one of the most dynamic sectors of the global economy. Depending on the region's features and attractions and the level of tourism development, tourism may produce from a few - c.a. $4-5 \%$ of region GDP to even $40 \%$. An increasing number of destinations have opened up to and invested in tourism turning it into a key driver of socio-economic progress in many regions. It is estimated that 1 in 11 jobs worldwide is directly or indirectly related to tourism services. The number of international tourist arrivals surpassed 1 billion in 2013, rising each year about $5 \%$. Europe, from the beginning of the history of contemporary tourism, has been the main tourist destination in the world. In the 21 st century we are facing several changes regarding the tourism development trends: globalization and individualization, culture and sport, local culture and international links. One of the strongest trends in tourism is that Europe is beginning to lose its prominence as a tourist destination. It still accounts for over $52 \%$ of international tourist arrivals (UNWTO Tourism Highlights, 2014) but is developing less dynamically than other destinations. ${ }^{1}$ The strongest grow occurs in Asia and the Pacific region, with is sub-region as a leader: The South-East Asia (10\% grow). What is more, arrivals in emerging destinations are expected to rise twice as much as in developed destinations by 2030 . As a result, the tourism market share is predicted to be $57 \%$ for emerging economies (UNWTO Tourism Highlights, 2014). These statistics are impressive and give hope and reasons to think of tourism as the great opportunity for regions to create jobs and fight the unemployment especially among the young people. It gives possibilities to increase incomes to the regional budget, revalidate and develop infrastructure and, as a consequence, rise the quality of life of the local societies at the tourist destinations. On the other hand, it appears that the impact of the dynamically but unsustainably developed tourism may turn negative and harmful

${ }^{1}$ UNWTO Tourism Highlights, 2014 Edition, http://mkt.unwto.org/publication/unwto-tourism-highlights-2014edition. 
for the destination. The environmental impact is the most commonly recognized. Negative impacts of tourism occur when the level of visitor use is greater than the environment's ability to cope with this use within the acceptable limits of change. ${ }^{2}$ Uncontrolled massive tourism can cause potential and real threats to many natural areas all over the world. It can put enormous pressure on an area and lead to impacts such as soil erosion, increased pollution, discharges into the sea, natural habitat loss for endangered species.

But there are also the other aspects of the problem such as social or cultural issues including ethics or gender equality. The socio-cultural impacts of tourism on host communities are effects of direct and indirect relations with tourists, and of interaction with the tourism industry. The host communities appear to be the weaker party in interactions with their guests and service providers, leveraging any influence they might have. The impacts arise when tourism brings about changes in value systems and behavior thereby threatening indigenous identity. It also happens that changes often occur in community structure, traditional life styles, ceremonies and morality: may lead to the loss both of authenticity and traditional character of local communities. As a consequence, such a community may lose its touristic value. As far as economic aspects are concerned, there are many hidden costs to tourism, which can have unfavorable economic effects on the host community. What is more: in most all-inclusive package tours, about $80 \%$ of travelers' expenditures go to the airlines, hotels and other international companies (who often have their headquarters in the travelers' home countries), and not to local businesses or workers. These zones of potential problems should lead to direct association: monitoring tourism development is necessary. It may enable to avoid or at least minimalize the risk of dysfunctions of the tourism development in different spheres of tourism influence. The theory which promotes measuring tourism impact in different zones and concentrating on obtaining the balance among them is the sustainable tourism management.

\section{Sustainable development in tourism - an evolution of the approach to sustainability in tourism}

The concept of the sustainable development of tourism has not been created in the $21 \mathrm{st}$ century. It dates back to the mid-20th century, when some researchers interested in the dynamically developing economy after the destruction of World War II noticed that the changes take place without due regard for environment. ${ }^{3}$ It was then that the idea of "ecological awakening" began to sprout following a number of ecological disasters. ${ }^{4}$ In the course of several decades to follow, numerous debates on the direction of development led to the theory of sustainable development. It was first taken up in international organizations - UN, UNESCO, later World Tourism Organization (WTO, now UNWTO), then in a more local scope, and has been under discussion until today. The statement from the Brundtlandt Report (World Commission on Environment and Development - WCED),

${ }^{2}$ www.unep.org/resourceefficiency/Business/SectoralActivities/Tourism/TheTourismandEnvironment Programme/FactsandFiguresaboutTourism/ImpactsofTourism/EnvironmentalImpacts/TourismsThreeMainImpact Areas/tabid/78776/Default.aspx.

${ }^{3}$ M. Burchardt-Dziubińska, A. Rzeńca, D. Drzazga, Zrównoważony rozwój, naturalny wybór, Wydawnictwo Uniwersytetu Łódzkiego, Łódź 2014, p. 11.

${ }^{4}$ M. Burchardt et al..., p. 12. 
"Humanity has the ability to make development sustainable to ensure that it meets the needs of the present without compromising the ability of future generations to meet their own needs," coined in 1987, remains valid until today. The EU defines the theory of sustainable development as a vision offering a development which incorporates short- and long-term goals, local and global activities, while respecting the social, economic, and natural environment as both independent and inseparable aspects of human existence. There is one key remark here that neither the theory of sustainable development nor lawmaking shall be enough unless the idea finds its place in the awareness of citizens. The change in the global scale will become fact only when average consumers start making their everyday choices in the conviction that the sustainable development is possible.

For the above reasons, sustainable tourism is less a kind of tourism than a way of thinking about it, both on the side of supply and demand. The definition of sustainable tourism also goes several decades back in history. A review of the definitions of sustainable tourism is given by A. Kowalczyk, who quotes Krippendorf's definition of alternative tourism as the precursor to sustainable tourism (1986), Szwichtenberg's - also alternative tourism - and then by authors discussing sustainable tourism. In the 1990s, T. Forsyth defined sustainable tourism as one which does not bring negative environmental or social consequences. ${ }^{5}$ Among the numerous Polish authors, D. Zaręba defines sustainable tourism as referring to the concept of eco-development and states that the key notion in the theory of sustainable development is order. Eco-development has to reconcile four types of order: ecological, social, economic, and spatial. ${ }^{6}$ The spatial order is the distinctive component of this definition, being a certain innovation and related to the modern perception of the tourism product. At present, the tourism product is perceived more and more often in terms of destination: the environment in which the core product is embedded. For this reason the sustainable development is becoming the key strategy for managing a tourist destination on a difficult, highly saturated, and competitive tourism market.

\section{Innovations in tourism - management innovations}

On the highly saturated modern tourism market, where the role of price competition is marginal, the tourism product, taken both individually (as an individual service, service package, tourist attraction, or type of tourism) and comprehensively as a tourist destination, has to strive to find its own way to the market, then to distinguish itself from competing products, and finally to survive on the difficult market. Depending on the phase of the lifecycle of the product, individual tasks and specific actions are going to differ. Still, however, they should retain innovativeness as their common denominator.

Figure 1 shows the development phases of a tourist product, also related to a tourist destination understood as a product, and the points in time when implementing innovations (of product, organizational and management, marketing, or technological kind) may be a response to downward trends.

\footnotetext{
${ }^{5}$ A. Kowalczyk, Turystyka Zrównoważona, Wydawnictwo Naukowe PWN, Warszawa 2010.

${ }^{6}$ D. Zaręba, Ekoturystyka. Wyzwania i nadzieje, Wydawnictwo Naukowe PWN, Warszawa 2010.
} 


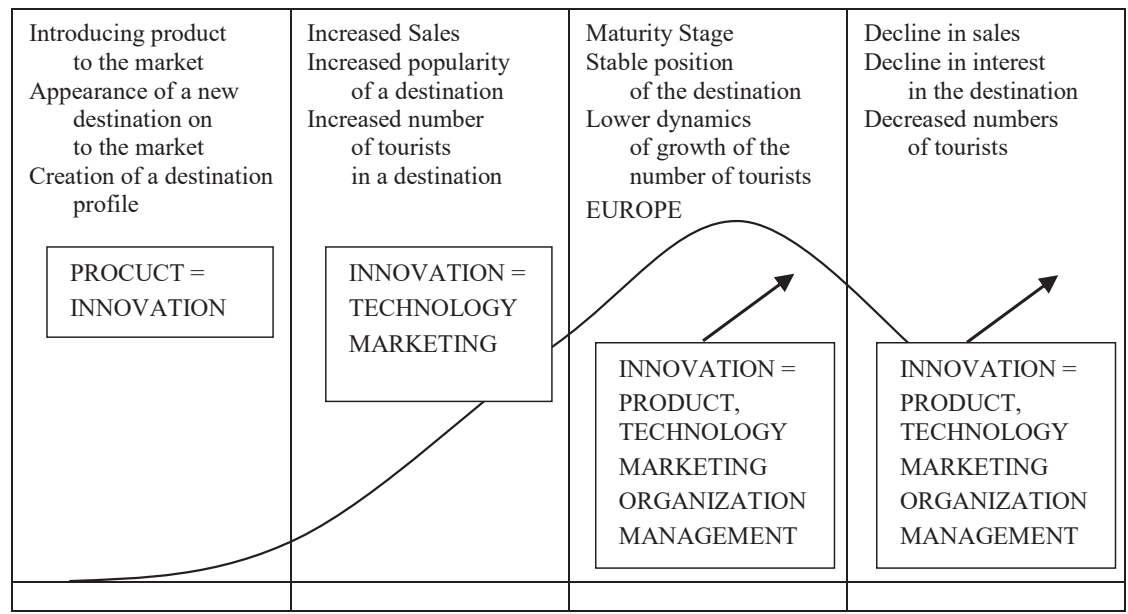

Figure 1. Product life circle and types of innovation

Sorce: the author's own work.

Due to the service nature of the tourist sector, innovation takes an immaterial form of improvement rather than of useful invention of the technological patent. There are different strategies of implementing innovation as well which may be part of the development strategy of a company or a strategically managed destination, or a reaction to a situation on the market. The following breakdown of innovative actions is conventional and meant only to show various ways of innovative thinking and demonstrate that various actions, often underestimated both at the level of a tourist destination and in the case of individual enterprises, may be conducive of significant changes.

\begin{tabular}{|c|c|c|}
\hline Innovation implementation strategy & \multicolumn{2}{|c|}{ Type of innovation } \\
\hline Ad hoc & $\begin{array}{l}\text { - Marketing innovation } \\
\text { - Organizational innovation }\end{array}$ & 吾 \\
\hline Scientific approach to the process of innovation & $\begin{array}{l}\text { - Product innovation } \\
\text { - Marketing innovation } \\
\text { - Technological innovation } \\
\text { - Organizational innovation } \\
\text { - Innovation in management process }\end{array}$ & 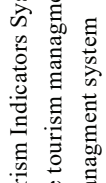 \\
\hline $\begin{array}{l}\text { Innovation seen as a complete knowledge } \\
\text { and learning process }\end{array}$ & $\begin{array}{l}\text { - Product innovation } \\
\text { - Marketing innovation } \\
\text { - Technological innovation } \\
\text { - Organizational innovation } \\
\text { - Innovation in management process }\end{array}$ & 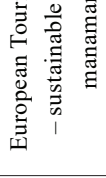 \\
\hline
\end{tabular}

Figure 2. Implementation strategies and types of innovation in tourism

Source: the author's own work.

The present-day notion of a tourist product differs from its traditional understanding as a package of services or an individual service. While this approach is still valid, of course, from 
the viewpoint of the global and highly saturated tourist market, it seems more significant on the strategic planning level to define a tourist product as a comprehensive perception of a given place (tourist destination), previously identified with the so-called extended product. In other words, modern tourist product may be understood as the "attractions and environmental features, facilities and services, communication availability, the image of the visited area, and the price which, related to quality, is also part of the image." According to the strategic management, conceived as a certain philosophy of leading an organization (or region) which gives grounds to draft directions for development and, in a longer perspective, provides the conditions for the realization of intended goals $^{8}$, the management of development of tourism in a region should encompass many areas of functioning of tourism economy as well as, strictly speaking, the areas of the functioning of the region which are affected by tourism. Strategic documents related to the development of tourism in a region reflect this now predominant trend in world tourism. In the document "Directions for Tourism Development until 2015" by the Ministry of Sport and Tourism, the integration of tourist products and offer within regions is the operational goal relative to the shaping of competitiveness of regions. It mentions the "shaping of the tourist space" as a priority area. ${ }^{9}$ Another document by the Ministry of Sport and Tourism, the "Program for Tourism Development until 2020", following a SWOT analysis of tourism in Poland, present the following perspective of its development:

"A modern and open tourism economy, based on intelligent specialization of tourism in the regions of Poland, knowledge-based, being one of the key factors of regional development, and strengthening the competitiveness of the country in the EU." 10 In order to achieve this goal, or realize such an ambitious vision, it is necessary to comprehensively analyze the potential of the region, to diagnose it, and formulate a potential-based destination profile. It is also necessary to recognize the character of interactions between the phenomenon of tourism and the economy and environment (natural, social, and cultural) of the region. The monitoring of many of the issues mentioned above and diagnosing the key points of the development and the influence of tourism on a region is made possible by the tool for sustainable management of tourism in a region developed by the European Committee: the European Tourism Indicators System (ETIS).

\section{European Tourism Indicators System (ETIS) for sustainable destinations as a tourism managing tool in regitons}

European Tourism Indicator System Toolkit was commissioned by the European Commission based on the vast research and observation on contemporary tourism trends, the challenges that tourism market and the need of enforcing the competitive position of Europe as tourist destination

${ }^{7}$ E. Dziedzic, Zaangażowanie finansowe sektora publicznego $w$ rozwój podaży turystycznej $w$ miastach, in: Turystyka na obszarach miejskich - uwarunkowania rozwoju, narzędzia promocji, Zeszyty Naukowe Uniwersytetu Ekonomicznego w Katowicach, Katowice 2012.

${ }^{8}$ M. Dołhasz, J. Fudaliński, M. Kosala, H. Smutek, Podstawy Zarzadzania, Koncepcje - strategie - zastosowania Wydawnictwo Naukowe PWN, Warszawa 2009.

${ }^{9}$ Kierunki rozwoju turystyki do 2015 roku, Ministerstwo Sportu i Turystyki, Warszawa 2008.

${ }^{10}$ Program Rozwoju Turystyki do roku 2020, Ministerstwo Turystyki i Sportu, Warszawa, June 2014. 
on the global scale. The European Tourism Indicator System is designed to show that the sustainable tourism development in a region is a process and to give to the destinations some suggestions and accurate indicators that may be useful while introducing sustainable management. It should raise awareness of the need of sustainability in tourism and its real meaning. Sustainable management is not only "not to harm" the environment. It is planning, introducing, monitoring and measuring results in a different fields of interests. Technically, it consist of 27 core and 40 optional indicators. It can be integrated to the existing destination monitoring system or introduced as a basic tool. The great advantage of this system is the integration of public and private space, fields of interest (e.g., environmental impact, socio-cultural, economical value). As we already know, the future competitiveness of tourism system is closely linked to its sustainability, so the European Commission points out some key motivations for monitoring destination, amongst which one can find: improved information leading to better decision making, managing and minimizing risk, prioritization of projects, and benchmarking performance.

\section{Core and optional indicators}

The indicators were developed over a two-year period. Core Indicators are identified as being the most important and Optional Indicators are more relevant for the destinations that have more advanced monitoring systems in place. The ETIS project has been tested in two phases of the pilot studies in more than 100 European regions. After each phase the experiences have been shared and the comments taken into account for the future improvement of ETIS. Generally, the system of the indicators has been agreed to be relevant, clear and useful. The structure of indicators in presented in Table 1.

Table 1. Selected Core and Optional Indicators of ETIS

\begin{tabular}{|c|c|c|c|}
\hline Section & Criteria & Indicator & $\begin{array}{c}\text { Core } \\
\text { or optional }\end{array}$ \\
\hline 1 & 2 & 3 & 4 \\
\hline \multirow{6}{*}{ 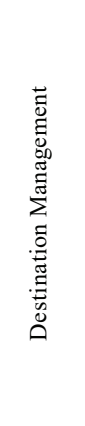 } & \multirow{2}{*}{$\begin{array}{l}\text { Sustainable Tourism } \\
\text { Public Policy }\end{array}$} & $\begin{array}{l}\text { Percentage of the destination with a sustainable tourism strategy/action } \\
\text { plan, with agreed monitoring, development control and evaluation } \\
\text { arrangement }\end{array}$ & Core \\
\hline & & $\begin{array}{l}\text { Number of residents satisfied with their involvement and their influence } \\
\text { in the planning and development of tourism }\end{array}$ & Optional \\
\hline & \multirow[t]{2}{*}{ Customer Satisfaction } & $\begin{array}{l}\text { Proportion of visitors that are satisfied with their overall experience } \\
\text { in the destination }\end{array}$ & Core \\
\hline & & Rate of repeat/return visitors (within 5 years) & Optional \\
\hline & \multirow{2}{*}{$\begin{array}{l}\text { Information } \\
\text { and Communication }\end{array}$} & $\begin{array}{l}\text { The range of visitors who note that they are aware of destination } \\
\text { sustainability efforts Percentage }\end{array}$ & Core \\
\hline & & $\begin{array}{l}\text { The percentage of businesses that communicate their sustainability efforts } \\
\text { to visitors in their products, marketing, or branding }\end{array}$ & Optional \\
\hline
\end{tabular}




\begin{tabular}{|c|c|c|c|}
\hline 1 & 2 & 3 & 4 \\
\hline \multirow{9}{*}{ 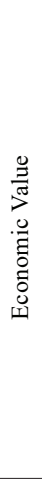 } & \multirow{3}{*}{ Tourism Flow } & Number of tourist nights per month & Core \\
\hline & & Relative contribution of tourism to the destination's economy (\% GDP) & Optional \\
\hline & & $\begin{array}{l}\text { Daily spending per tourist (accommodation, food and drinks, other } \\
\text { services) }\end{array}$ & Core \\
\hline & \multirow{2}{*}{$\begin{array}{l}\text { Tourism Enterprise(s) } \\
\text { Performance }\end{array}$} & Average length of stay of tourists (nights) & Core \\
\hline & & $\begin{array}{l}\% \text { of ten largest tourism enterprises involved in destination management/ } \\
\text { cooperative marketing }\end{array}$ & Optional \\
\hline & \multirow{2}{*}{$\begin{array}{l}\text { Quantity and Quality } \\
\text { of Employee }\end{array}$} & Direct tourism employment as a rate of total employment & Core \\
\hline & & Percentage of jobs in tourism that are seasonal & Optional \\
\hline & \multirow{2}{*}{ Tourism Supply Chain } & $\begin{array}{l}\text { Quota of tourism enterprises actively taking steps to source local, } \\
\text { sustainable, and fair trade goods and services }\end{array}$ & Core \\
\hline & & $\begin{array}{l}\text { Percentage of the destination covered by a policy promoting local, } \\
\text { sustainable and/or fair trade products and services }\end{array}$ & Optional \\
\hline \multirow{7}{*}{ 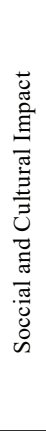 } & \multirow{2}{*}{$\begin{array}{l}\text { Community/Social } \\
\text { Impact }\end{array}$} & Proportion of tourists/visitors per 100 residents & Core \\
\hline & & $\begin{array}{l}\text { Number of residents who are satisfied with tourism in the destination } \\
\text { (per month/season) }\end{array}$ & Optional \\
\hline & \multirow[b]{2}{*}{ Gender Equality } & Rate of men and women employed in the tourism sector & Core \\
\hline & & $\begin{array}{l}\text { Number of tourism enterprises where the general manager position is held } \\
\text { by a woman }\end{array}$ & Optional \\
\hline & \multirow{3}{*}{ C.3 Equality/Accessibility } & $\begin{array}{l}\text { Range of commercial accommodation with rooms accessible to people } \\
\text { with disabilities and/or participating in recognised accessibility schemes }\end{array}$ & Core \\
\hline & & $\begin{array}{l}\text { Area of destination served by public transport that is accessible to people } \\
\text { with disabilities and people with specific access requirements }\end{array}$ & Optional \\
\hline & & $\begin{array}{l}\text { Percentage of visitor attractions that are accessible to people with } \\
\text { disabilities and/or participating in recognised accessibility schemes }\end{array}$ & Core \\
\hline \multirow{11}{*}{ 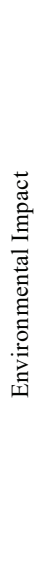 } & $\begin{array}{l}\text { Reducing Transport } \\
\text { Impact }\end{array}$ & $\begin{array}{l}\text { Number of tourists and same day visitors using different modes of } \\
\text { transport to arrive at the destination (public/private and type) }\end{array}$ & Core \\
\hline & \multirow[t]{2}{*}{ Solid Waste Management } & $\begin{array}{l}\text { Waste volume produced by destination (tonnes per resident per year } \\
\text { or per month) }\end{array}$ & Core \\
\hline & & Percentage of tourism enterprises separating different types of waste & Optional \\
\hline & \multirow{2}{*}{ Water Management } & $\begin{array}{l}\text { Fresh water consumption per tourist night compared to general population } \\
\text { water consumption per person night }\end{array}$ & Core \\
\hline & & $\begin{array}{l}\text { Number of tourism enterprises with low-flow shower heads and taps } \\
\text { and/or dual flush toilets/waterless urinals }\end{array}$ & Optional \\
\hline & Energy Usage & $\begin{array}{l}\text { Energy consumption per tourist night compared to general population } \\
\text { energy consumption per person night }\end{array}$ & Core \\
\hline & \multicolumn{3}{|l|}{ Landscape and } \\
\hline & Biodiversity Management & Area of destination $\left(\mathrm{in} \mathrm{km}^{2}\right)$ that is designated for protection & Core \\
\hline & Light and Noise & The destination has policies in place that require tourism enterprises & \\
\hline & Management & to minimise light and noise pollution & Core \\
\hline & Bathing Water Quality & Level of contamination per $100 \mathrm{ml}$ (faecal coliforms, campylobacter) & Core \\
\hline
\end{tabular}

Source: European Tourism Indicators System for Sustainable Destinations, European Commission, European Commission 2013, Brussels.

\section{Introducing ETIS as a process}

The introduction of the ETIS (for sustainable development of tourism in a region) is a process which requires timing and is strongly based on the cooperation of entities making up the 
"consortium": the organization created to achieve a specific goal. The implementation stages of the process are defined as follows:

\section{Stage I: Building awareness}

In the context of project realization, building the awareness of implementing the system aimed at the management of sustainable development of the destination means informing and raising awareness of the greatest possible number of people, enterprises, and organizations regarding the planned actions, their scope, and significance. Building awareness also seems to be an activity preceding decisions on implementing the ETIS system. From the point of view of local authorities as well as all participants of the tourism market in a given region, there already has to be an awareness of the advantages of introducing sustainable management of tourism in order to argue for the efforts which have to be made if the project is to succeed. Thus, what is important is not only the general knowledge about the introduced project but also belief in the essence of sustainable development of tourism.

\section{Stage II: Creating the profile of the destination}

Every region which intends to invest, economically and organizationally, in the development of tourism, needs to have an awareness of the assets, competitive advantages, and opportunities for tourism development it has. However, each of this areas is different, and it is based on this "difference" that it should build its image as a tourist destination. Dependent on the developed product strategy and destination profile, individual parameters of the system can be more or less significant, revealing the strengths and weaknesses of the region. A significant question in a slightly different dimension is setting clear limits of the destination, which will in turn influence the choice of people, organizations, and enterprises involved in the project.

\section{Stage III: Forming the executive team}

The next and particularly important stage is to create an executive team by diagnosing people, enterprises, and organizations belonging to various categories of tourist traffic participants. Including representatives of the private and public sector, and the sectors of enterprises and organizations in the team will enable to gather comprehensive data. A model composition of an executive team will be presented below, in the section devoted to the possibilities of implementation of a system for the sustainable development of tourism.

\section{Stage IV: Establishing roles and responsibilities within the team}

It is necessary to establish clear roles within the team. As the sustainable management system requires gathering and monitoring of data from various fields, the clear definition of their scope is of crucial importance to the thoroughness of the project and reliability of the results and conclusions we want to draw for the destination.

\section{Stage V: Gathering and creating inventory of data}

This stage involves the collection and recording of the data which should exist in one place but form a distributed system. The gaps in the collected data, especially those considered as crucially important for the destination, will require intensified operational activities. In addition, 
the destination receives feedback regarding monitoring, or rather the lack of certain fields in the operation of the destination.

\section{Stage VI: Data analysis}

The data collected based on indicators needs to be analyzed to find both the strengths and gaps in the sustainable development. The conclusions of the analysis should lead to setting goals, necessary and possible to realize, and to plans of actions to take in order to achieve them. Each destination can have different priorities. In one case, the key factor may be the use of water by tourist in the region where there is a shortage of it, which will require implementing appropriate solutions. In another, the analysis may reveal exceeding the norms of noise or atmospheric pollution, inequality in employment, disturbed comfort of life of inhabitants by a too great accumulation of tourist arrivals in a short time, or a detrimental structure of tourist spendings in the region. Each of these shall require taking different actions.

\section{Stage VII: Ensuring the continuation of the project}

Making an effort to introduce the sustainable management system should not be a one-time action. It would be appropriate to treat it as a long-term project and build a strategy upon its basis with a longer time scope.

\section{Analysis of the process of introducing ETIS and ways to streamline it SWOT analysis of introducing ETIS and its structure based on European experience}

The first pilot phase of introducing the EU project which took place between 15 July 2013 and 15 April 2014 involved 104 regions, 50 of which presented their results to the European Committee. Among these participants, 35\% were urban destinations, 23\% were communes, $28 \%$ were non-administrative regions, and 7\% were provinces. There was much activity of the Southern European destinations, in particular from Italy and Greece. It is worth to adduce some of the data reported by the European Committee (collected from 50 regions) as well as individual participants. It was shown that:

1. More than $50 \%$ of destinations report significant overpopulation during the tourist season, regardless of the destination type (seaside, urban, or rural).

2. $26 \%$ of destinations did not have a system to monitor sustainable development before.

3. Among destinations which had a system to monitor tourism, the majority declared to have at least 3 distributed systems.

Some changes to the structure of indicators were suggested, as well as a new group of indicators: innovation and entrepreneurship. It was also proposed to increase support by the European Commission, especial at the stage of raising the awareness of the need for sustainable management in tourism. The majority of destinations decided to continue to participate in the project and found it very useful, evaluating ETIS as an effective system of managing a tourism 
destination. Unfortunately, no region of Poland took part in either the 1st or the 2nd pilot phase of the project. The table below presets the SWOT analysis of introducing ETIS in a region based on the experience of the regions participating in the pilot phase of the study and on the analysis of the document.

Table 2. SWOT analysis of introducing ETIS in a region

\begin{tabular}{|c|c|}
\hline Strengths & Weaknesses \\
\hline $\begin{array}{l}\text { Characteristics and structure of ETIS: } \\
\text { - System of indicators and the system structure which reflects all } \\
\text { spheres of influence of tourism } \\
\text { - Instructions on the stages of introducing ETIS } \\
\text { Introduction of ETIS: } \\
\text { - Cooperation between various entities at the local level } \\
\text { - Strengthening of the awareness of sustainable development } \\
\text { among project participants, inhabitants, and tourists } \\
\text { - Long-term economic benefits due to correction of expenditures } \\
\text { related to the development of tourism (e.g. energy) and } \\
\text { increasing the number of tourism by improving the region } \\
\text { brand. }\end{array}$ & $\begin{array}{l}\text { Characteristics and structure of ETIS: } \\
\text { - Difficulties in forming the executive group: on one hand, } \\
\text { the excessive number of members; on the other, there were } \\
\text { areas which yielded no data due to the lack of organizations } \\
\text { representing a given sphere. } \\
\text { - Technical issues in creating the inventory of data (no idea } \\
\text { for a system) } \\
\text { - Obtaining data from participants } \\
\text { - Impossibility to define certain indicators } \\
\text { Introduction of ETIS: } \\
\text { - Lack of human and monetary resources }\end{array}$ \\
\hline Opportunities & Threats \\
\hline $\begin{array}{l}\text { - Building the positive image of the destination } \\
\text { - Increasing the competitiveness of a region by, among other } \\
\text { things, caring for spatial order and tourist and recreation space } \\
\text { - Improving the quality of life of inhabitants by developing } \\
\text { infrastructure and quality of public space } \\
\text { - Decreasing environmental cost of tourism development } \\
\text { - Increasing the number of tourists in the region }\end{array}$ & $\begin{array}{l}\text { - Insufficient awareness of the theory of sustainable development } \\
\text { of tourism in a region, no interest in introducing ETIS } \\
\text { - Not ensuring the continuation of the project by insufficient use } \\
\text { of obtained results } \\
\text { - Lack of long-term strategies for sustainable development } \\
\text { of tourism based on obtained results } \\
\text { - Insufficient awareness of the importance of the theory } \\
\text { of sustainable development among potential participant } \\
\text { of the project on the side of tourism supply } \\
\text { - Lack of funds }\end{array}$ \\
\hline
\end{tabular}

Source: the author's own work.

\section{Gritical points diagnosis in the processes of introducing ETIS - improvenent proposals}

A vast majority of the European regions participating in the pilot phases of introducing the ETIS have declared it to be appropriate and effective, and assessed the structure of its indicators as very good. However, some problems have been signaled as well, having occurred at various stages of introducing the process. The table below presents the selected difficulties in introducing the system and the possibilities of resolving them. 
Table 3. Problems reported by European regions in the process of introducing ETIS

\begin{tabular}{|c|c|c|}
\hline Stage of the process & Problem encountered & Possible solutions \\
\hline Building awareness & $\begin{array}{l}\text { The reporting destinations declared } \\
\text { difficulties in carrying out wide- } \\
\text { ranging informational actions due to, } \\
\text { e.g., little interest of the media, low } \\
\text { availability of communication tools, } \\
\text { and insufficient involvement of local } \\
\text { authorities. }\end{array}$ & $\begin{array}{l}\text { Creation of a www platform - before launching the project } \\
\text { - tied to the web page of the destination: informative } \\
\text { at first, promoting sustainable development, and providing } \\
\text { objective knowledge about both the project and sustainable } \\
\text { development. } \\
\text { Attempts to increase interest of the media by showing the } \\
\text { advantages of introducing the project. } \\
\text { A "project study" for media representatives. } \\
\text { Recognizing units of local government as members } \\
\text { of the consortium. }\end{array}$ \\
\hline $\begin{array}{l}\text { Formation } \\
\text { of the consortium }\end{array}$ & $\begin{array}{l}\text { Formation of the consortium was not } \\
\text { a major difficulty, yet sometimes they } \\
\text { became too comprehensive, leading } \\
\text { to difficulties in managing their work. } \\
\text { In many cases, the lack of activity } \\
\text { of individual participants made the } \\
\text { realization of the project difficult. }\end{array}$ & $\begin{array}{l}\text { The formation of a consortium should be preceded by } \\
\text { the analysis of areas to be covered with competencies } \\
\text { (project interdisciplinarity) while minimizing the size } \\
\text { of the executive group. } \\
\text { Setting a timeframe for works and the ways to enforce } \\
\text { obligations - motivation. }\end{array}$ \\
\hline $\begin{array}{l}\text { Distribution of roles } \\
\text { and responsibilities } \\
\text { within the consortium }\end{array}$ & $\begin{array}{l}\text { Difficulties revealed at this stage: } \\
\text { - setting timeframes for carrying out } \\
\text { individual tasks, } \\
\text { - problems determining the way to } \\
\text { gather information, } \\
\text { - lack or limited availability } \\
\text { of information sources, } \\
\text { - some areas were not reflected in the } \\
\text { consortium - lack of someone } \\
\text { responsible for or able to gather data } \\
\text { in some categories of information, }\end{array}$ & $\begin{array}{l}\text { Fixing a detailed schedule for works and monitoring } \\
\text { the advancement of realization. } \\
\text { A thorough analysis of indicators before beginning the realization } \\
\text { of the project and distributing roles: in order to decide which } \\
\text { data is secondary and which is primary, and how it is going } \\
\text { to be obtained. } \\
\text { In the case when it is impossible to gather data based on the } \\
\text { indicators suggested by ETIS: replacing it with other, } \\
\text { attainable indicators appropriate for a given issue. }\end{array}$ \\
\hline Collection of data & $\begin{array}{l}\text { As many as } 83 \% \text { of destinations } \\
\text { declared issues with collecting } \\
\text { data based on indicators: the main } \\
\text { issue was motivating the members } \\
\text { of the consortium to fulfill their } \\
\text { responsibilities and influencing } \\
\text { individual project members. }\end{array}$ & $\begin{array}{l}\text { Appropriate distribution of tasks and competencies in such } \\
\text { a way that gathering data becomes part of every-day actions } \\
\text { of a given consortium member. } \\
\text { Publishing of current stages of project realization } \\
\text { on a www platform: information about partners } \\
\text { who do not fulfil their obligations. }\end{array}$ \\
\hline Data analysis & $\begin{array}{l}\text { The analysis of data did not lead to } \\
\text { developing appropriate strategies } \\
\text { for the future (e.g. based on revealed } \\
\text { irregularities, barriers, or weaknesses), } \\
\text { therefore unsatisfactory results were } \\
\text { declared. } \\
\text { The difficulty in sharing the obtained } \\
\text { knowledge and experiences with other } \\
\text { regions was also indicated. }\end{array}$ & $\begin{array}{l}\text { Sustainable development of tourism should be treated as } \\
\text { a strategic goal, not as an experiment: introduction of ETIS } \\
\text { allows to diagnose problems and barriers to development } \\
\text { in various areas. The information that they occurred is } \\
\text { not of high (practical) value in itself for the development } \\
\text { of tourism in a region: what is valuable is incorporating the } \\
\text { conclusions in developmental strategies and recovery plans. } \\
\text { Creation of a platform for the exchange of experiences between } \\
\text { regions participating in the project: actions by the European } \\
\text { Committee. }\end{array}$ \\
\hline $\begin{array}{l}\text { Ensuring } \\
\text { the continuation } \\
\text { of the project }\end{array}$ & Lack of resources to continue the project. & $\begin{array}{l}\text { Strategic planning in financial category: in a longer term than } \\
\text { the planned introduction of the system in the 1st phase. } \\
\text { The project is very good for grants: its interdisciplinarity } \\
\text { and the cooperation of the private, local government, } \\
\text { and scientific sectors brings opportunities to apply for } \\
\text { resources. }\end{array}$ \\
\hline
\end{tabular}

Source: the author's own work. 


\section{Conclusion}

The ETIS is a relatively new initiative, and its introduction in the European regions over 2 pilot phases is aimed at its further improvement. It is a flexible system, able to function in connection with the monitoring systems already present in the destination or as an integrating tool. In spite of reported difficulties, the majority of destinations declares appropriateness of introducing the system and willingness to continued realization of the project. The most important advantages of introducing ETIS seem to be the following aspects:

- the tourism economy in the region is strongly related with other areas of the economy: its sustainable development may contribute to the development in other fields,

- sustainable management of tourism is a component of a sustainable development system as such,

- sustained development of tourism incorporates social, environmental, and economic aspects, the monitoring of which, diagnosing problems, and eventually solving them benefits the comprehensive management of a region,

- the worldwide socio-economic trend promotes sustainable development in various fields (tourism: World Tourism Organisation, European Committee).

Sustainable development may contribute to creating the region brand according to the trends in modern management of a region.

Present-day tourists look for an original product matching their interests, one which meets specific quality standards, both as individual services and the perception of the destination as a whole. The creation of the destination brand and comprehensive improvement of the destination quality can be greatly helped by introducing the system of sustained management of tourism based on the European Tourism Indicator System Toolkit.

\section{References}

Burchardt-Dziubińska M., Rzeńca A., Drzazga D., Zrównoważony rozwój, naturalny wybór, Wydawnictwo Uniwersytetu Łódzkiego, Łódź 2014.

Dołhasz M., Fudaliński J., Kosala M., Smutek H., Podstawy Zarządzania, Koncepcje - strategie - zastosowania, Wydawnictwo Naukowe PWN, Warszawa 2009.

Dziedzic E., Zaangażowanie finansowe sektora publicznego w rozwój podaży turystycznej w miastach, in: Turystyka na obszarach miejskich - uwarunkowania rozwoju, narzędzia promocji, Zeszyty Naukowe Uniwersytetu Ekonomicznego w Katowicach, Katowice 2012.

Kowalczyk A., Turystyka Zrównoważona, Wydawnictwo Naukowe PWN, Warszawa 2010.

Zaręba D., Ekoturystyka. Wyzwania i nadzieje, Wydawnictwo Naukowe PWN, Warszawa 2010.

European Tourism Indicators System for Sustainable Destinations, European Commission, Brussels 2013.

Kierunki rozwoju turystyki do 2015 roku, Ministerstwo Sportu i Turystyki, Warszawa 2008, www.msport.gov.pl/ article/524-Kierunki-rozwoju-turystyki-do-2-15-roku.

Program Rozwoju Turystyki do roku 2020, Ministerstwo Turystyki i Sportu, Warszawa, June 2014.

UNWTO Tourism Highlights, 2014 Edition, http://mkt.unwto.org/publication/unwto-tourism-highlights-2014-edition.

www.unep.org/resourceefficiency/Business/SectoralActivities/Tourism/TheTourismandEnvironmentProgramme/ FactsandFiguresaboutTourism/ImpactsofTourism/EnvironmentalImpacts/TourismsThreeMainImpactAreas/ tabid/78776/Default.aspx. 


\section{ZRÓWNOWAŻONE ZARZĄDZANIE TURYSTYKĄ \\ JAKO ELEMENT INNOWACYJNEGO ZARZACDZANIA REGIONEM \\ NA PODSTAWIE EUROPEAN TOURISM INDICATORS SYSTEM \\ FOR SUSTAINABLE DESTINATIONS}

SŁOWA KLUCZOWE

STRESZCZENIE zrównoważony rozwój turystyki, innowacje w zarządzaniu turystyką

Artykuł prezentuje koncepcję wielopłaszczyznowego zarządzania turystyką w regionie poprzez wprowadzenie European Tourism Indicator System for Sustainable Destination stworzonego przez Komisję Europejską. To wszechstronne podejście wydaje się być innowacyjnym rozwiązaniem kwestii zarządzania turystyką w regionie, które stanowić może jeden z kluczowych elementów zarządzania rozwojem regionalnym sensu stricte dla wielu regionów europejskich. W artykule zaprezentowano strukturę ETIS (European Tourism Indicator System for Sustainable Destination) oraz zasady procesu wdrażania niniejszego systemu z uwzględnieniem uwag regionów uczestniczących w pilotażowej fazie wdrażania projektu koordynowanego przez Komisję Europejską. Równoległym i równoważnym celem artykułu jest rozpowszechnianie idei zrównoważonego zarządzania turystyką w regionie poprzez wdrażanie systemu ETIS, który prezentuje interdyscyplinarne podejście , mogące prowadzić do zwiększenia konkurencyjności regionów na współczesnym, globalnym rynku turystycznym. 